\title{
СО-КУЛЬТУРЫ РАКОВЫХ И НЕОПУХОЛЕВЫХ КЛЕТОК ДЛЯ ОЦЕНКИ ПРОТИВООПУХОЛЕВОГО ПОТЕНЦИАЛА В СКРИНИНГЕ 10000 СОЕДИНЕНИЙ
}

\author{
Д.А. Скворцов', И.В. Жиркин', Л.А. Васильева', М.А. Калинина², \\ О.А. Донцова ${ }^{2,1}$
}

${ }^{1}$ Химический факультет и факультет биоинженерии и биоинформатики, МГУ имени М.В.Ломоносова, 119991, РФ, Москва, Ленинские горы, 1/40.

${ }^{2}$ Сколковский институт науки и технологий, РФ, 121205, Москва, Большой бульвар, 30/1.

DOI: 10.19163/MedChemRussia2021-2021-37_E-mail: skvortsovdmitrya@gmail.com

Изучение низкомолекулярных соединений для поиска новых молекул для химиотерапии входит в список приоритетных областей для разработки лекарств от рака Комиссии по онкологии Lancet [1]. При этом одним из ключевых вопросов на раннем этапе их разработки является оценка селективности действия веществ на раковые клетки.

Тест выживаемости флуоресцентных клеток в сокультуре (FCCT, Рис 1) разработан для поиска веществ, избирательно цитотоксичных для раковых клеток. Со-культура клеток опухолевой и неопухолевой этиологии позволяет также принять во внимание некоторые эффекты микроокружения опухолевых клеток. Предложены две модели: клетки карциномы легкого A549_EGFP с иммортализованными фибробластами легкого VA13_Kat [2] и клетки рака молочной железы MCF7_EGFP с нераковыми клетками эпителия молочной железы MCF10A_Kat. Эксперимент включает всего три шага: посев клеток, добавление вещества и обнаружение сигнала. Анализ FССТ прижизненный и совместим с другими тестами.

В работе протестировано 10000 соединений и обнаружена как избирательность действия против опухолевых клеток производных ряда известных препаратов (бексаротены, комбретастатины, кумарины и др.), так и селективность неописанных ранее препаратов хиназолин-индолов, оксодиазолопиразинов, фенилпирролохиноксалинов и др.

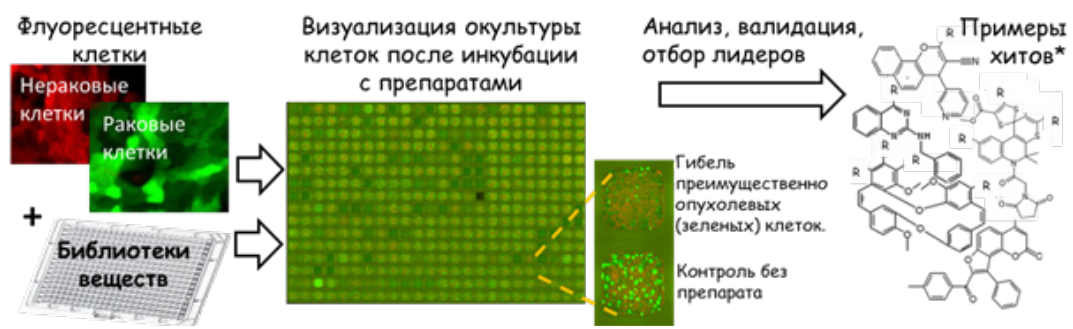

Puс 1. Схема тестирования. *Приведены примеры структур для иллюстрации химического разнообразия соединений-хитов, но не соединения-лидеры.

\section{Литература}

[1] Jaffee EM, Dang CV, et al. (2017) Future cancer research priorities in the USA: a Lancet Oncology Commission. Lancet Oncol 18, e653-e706, doi: 10.1016/S1470-2045(17)30698-8.

[2] Kalinina MA, Skvortsov DA, et al (2018) Cytotoxicity Test Based on Human Cells Labeled with Fluorescent Proteins: Fluorimetry, Photography, and Scanning for High-Throughput Assay. Mol Imaging Biol. 20, 368-377. 